\title{
Elections and Democratic Consolidation in Nigeria; \\ A Critique of 2011 Election
}

\author{
Alfa Patrick Innocent \\ e-mail:alfaintellectual@yahoo.com \\ Mobile No.: +234-8032404485 or +234-8051168950
Ahmadu Alhassan
Department of Social Science and Humanities
The Federal Polytechnic, Idah
Kogi State, Nigeria
e-mail: hassanacademics@gmail.com
Mobile No:+234-8065517987 \\ Adah George \\ Department Tourism \\ The Federal Polytechnic, Idah \\ Kogi State, Nigeria \\ adah70s@yahoo.com \\ Mobile No: +234-8068959870
}

\begin{abstract}
Elections and electoral processes are fundamental to the workings of every democratic setting of the modern state. Elections are the major hallmark of a democratic society. This paper argues that elections in Nigeria have not been able to contribute fundamentally to democratic consolidation. Specifically, the paper appraises the 2011 elections and the spate of violent reactions that followed the announcement of the results of the presidential elections despite the views of both domestic and international observers that the elections were credible. It opines that stakeholders must commit themselves to the task of conducting free and fair elections if the Nigerian fledgling democracy to enhance the speed of democratic consolidation.
\end{abstract}

Key words: Election, Democratic Consolidation, Democracy, Credible, Violence

\section{Introduction}

It is almost taken as given that the ascendancy of liberal democracy has witnessed increasing reduction of democratization especially in Africa 
to the "introduction of election and multi party politics", (Ntalaja,N.G,1997). This suggests the need to interrogate the significance of election within the democratic process. This is necessary especially against the backdrop of democratic rule in Africa collapsing through disputes over elections. To be sure, elections in Nigeria have not provided the necessary leeway for democratic sustenance. Consequently, they require a fundamental reappraisal.

The Nigeria's electoral experience has traced a parabola; it has oscillated from near success to outright failure and confusion culminating in a long era of regime instability occasioned by coups and counter-coups, civil war, annulment of elections, and post-election violence.

In the epoch of globalization of democracy with global standards and parameters for measuring the credibility of elections, it is pertinent for all stakeholders to rise to the challenges of credible elections and democratic consolidation in Nigeria.

\section{Conceptual Analyses}

\section{Election:}

An election is a formal decision making process by which a population chooses an individual to hold public office. Elections have been the usual mechanism by which modern representative democracy operates since the 17th century (Britannica, Encyclopedia 2009). Elections may fill offices in the legislature, sometimes in the executive, and judiciary, and for regional and local government.

Elections are the means through which the people exercise their sovereign right to choose who governs them and what the political and other priorities of their government should be. Democratic elections are thus the opportunity for the people to express their sovereignty through the ballot to confer legitimacy to their government, renew its mandate if necessary or withdraw from it the authority to govern. This is the basis of accountable government. (INEC, 2011). 
For Gwinn and Nortan, (1992), election is the formal process of selecting a person for public office or accepting or registering a political proposition by voting. They state further that an election is one of the means by which a society may organize itself and make specified formal decisions, adding that where voting is free, it acts simultaneously as a system for making certain decisions regarding the power relations in a society, and as a method for seeking political obedience with a minimum of sacrifice of the individual's freedom. The essence of a democratic election is freedom of choice.

For Eya (2003), election is seen as the selection of a person or persons for office as by ballot and making choice as between alternatives. Eya defines Electoral process as the method adopted in the selection of persons for political offices. He further sees electoral frauds or malpractices as improper, illegal, deceitful or immoral behaviours and conducts which vitiate free and fair electoral processes. A fair electoral process according to him, must have some basic structures, which include: statutory provisions establishing the electoral Bodies, Delineation of wards/constituencies, Registration of political parties, Registration of voters, Recruitment and training of ad-hoc staff, Procurement of electoral material, logistic, screening of candidates, provision of polling agents monitoring agents, actual voting, accreditation of voters, counting votes and providing avenues for settlement of disputed results.

Onyeka (2002) elucidates what characterizes a proper electoral process. For him, the basic objective of election is to select the official decision makers who are supposed to represent citizens -interest. He posits that an electoral process reinforces the concept of self-rule, celebrates it and legitimizes governmental power. Elections, according to Onyeka, extend and enhance the amount of popular participation in the political system adding electoral history started with restrictive voting based on property ownership and tax payment. The basic constituents of the electoral process according to Onyeka, include: political parties, political opinions, pressure groups and the mass media. They all converge on the electoral process to determine whom the leaders would be and ensure that the elected official will represent their constituencies 
effectively.

Similarly, the 1987 Political Bureau Report gave a lucid clarification and interpretation of elections and electoral processes.

It states that four basic conditions are necessary for the holding and conduct of free and fair elections. These include:

a. An honest competent, non-partisan administration to run elections.

b. Enabling rules and regulations-Electoral laws;

c. A developed system of political parties.

d. An independent judiciary to interpret electoral laws.

In many countries with weak rule of law, the most common reason why elections do not meet international standards of being "free and fair" is interference from the incumbent government. Dictators may use the powers of the executive (police, martial law, censorship, physical implementation of the election mechanism, etc) to remain in power despite popular opinion in favour of removal. Members of a particular faction in a legislature may use the power of the majority or supermajority (passing criminal laws, defining the electoral mechanisms including eligibility and district boundaries) to prevent the balance of power in the body from shifting to a rival faction due to an election.

Non governmental entities can also interfere with elections, through physical force, verbal intimidation, or fraud, which can result in improper casting or counting of votes. Monitoring for and minimizing electoral fraud is also an ongoing tasks in countries with strong traditions of free and fair elections.

Exploring the argument further, Wanyande (1987:80), posit that elections represent a way of making a choice that is fair to all- one that leaves each member of the electorate with the reasonable hope of having his alternative re-elected. An election is therefore an empirical demonstration of a citizen's liberty and political choice. It is for this that it serves to legitimize government. Properly managed, elections provide a veritable platform for conflict resolution and transformation outside 
the battlefield and without bloodshed. Hence the requirement of elections to be free and fair. Unfortunately, while much lip service is paid to the norms of free elections, too often a reality election is a travesty of democracy'. Devoid of the attributes of freeness and fairness, elections become an empty shell, lacking any real democratic content.

Elections ideally reflect and impact on the orderliness within society, and the stability, credibility and possibility of rejuvenating the political leadership through the change of decadent members of the elite and the advancement of the non-elite elements. Economically, elections, properly conducted, promote an environment of capital mobility and higher productivity, especially in a post-authoritarian and post-conflict political order in dire need of reconstruction and development.

Villalon (1998:16) rightly argued, "Elections themselves may be a strategy for maintaining power and many African elections... have been clearly intended to forestall change, or even strengthen the status quo." Elections as political stratagems for pursuing these agendas produce quasi-democracies in West Africa.

In liberal democratic theory, an election is a viable mechanism for consummating representative government. Apart from facilitating leadership succession, it promotes political accountability, citizens' participation and give voice and power to the people (Agbaje \& Adejumobi 2006:25-44). In other words, elections are an expression of the people's will. John Stuart Mill, in his treatise on representative government (Mill 1948:161-174) noted that: "the meaning of representative government is that the whole or some numerous portions of them, exercise through deputies periodically elected by themselves the ultimate controlling power, which in every constitution must reside somewhere. This ultimate power, they must possess in all its completeness".

According to Ake (2000), elections are a perversion of democracy because they connote popular but not delegated power. The nostalgia of direct democracy which Ake recounts is problematic in a complex and 
completed post-modern society. In any case, liberal democracy is in crisis in many countries, developed and developing (Adejumobi 2002). In a nutshell, elections are fast becoming a shadow of democracy (Adejumobi 2000).

\section{Democracy}

Democracy means different things to different people: a platform for power contestation and not the least a class struggle. Furthermore, the end of the Cold War has privileged liberal democracy globally as the most credible basis of governmental legitimacy (Adelaja, 2007).

In the views of Dahl, R. A. (2000) "within the enormous and often impenetrable thicket of ideas about democracy, it is possible to identify some criteria that a process for governing an association would have to meet in order to satisfy the requirement that all members are equally entitled to participate in the association's decisions about its policies". Dahl believes, at least five such standards abound. These are: effective participation, voting equality, enlightened understanding, exercising final control over the agenda and inclusion of adults. A democratic society, Dahl asserts, produces desirable consequences, avoiding tyranny, provision of essential rights, general freedom, self determination, moral autonomy, human development, protection of essential personal interests, political equality; in addition, he noted, modern democracies are peace-seeking and prosperous.

According to Makinda, S.M. (1996), "there is no clinical or scientific definition of liberal democracy, but some of the main features are free competition among political parties, periodic elections, and respect for fundamental freedoms of thought, expression, and assembly. There is plenty of evidence that such a system of government has the potential to encourage political stability and accountability and to help consolidate public institutions". Inspite of the absence of a universally acceptable definition of democracy, Makinda's description seem to be one of the most cogent and coherent. In fashioning out a working definition he noted: "in general terms democracy can be seen as a way of government firmly rooted in the belief that people in any society should be free to determine their own political, economic, social and cultural 
systems. But the form it takes can vary according to particular circumstances of every society. Indeed, whereas the principles of democracy are universal, their expression and practice cannot be transplanted wholesale from one community to another" Makinda also asserts that most African societies do not have a tradition of liberal democracy, and those leaders who took power after independence destroyed whatever checks and balances their constitutions contained.

At present, democracy has been transformed from its classical notion underpinned by the assumptions of government by the people; common good, the rationality of man; and the contradictory goal of liberty and equality (Rejai 1967:203)

Democratic peace theorists are of the opinion that non-democracies are societies in which violence and coercion prevail. In such societies, they observed, highly conflictive relations make internal democracy precarious, especially where there is strong opposition. The result is 'mistrust and fear within and outside government' (Maoz \& Russett 1993:625).

Consequently, a non- democratic state apparently lacks the institutional and behavioural constraints for war. It is argued that even a bad democracy '... does not give the leader of the government the incentive that an autocrat has to extract the maximum attainable social surplus from the society to achieve his personal objectives' (Olson 1993:571).

Huntington (1984:214) advances conditions for the institutionalization of democracy, namely: higher levels of economic well-being; the absence of extreme inequalities in wealth and income; greater social pluralism, including particularly a strong and autonomous bourgeoisie; a more market oriented economy, greater influence vis-à-vis the society of existing democratic states; and a culture that is monistic and more tolerant of diversity and compromise.

In another sense, democracy refers to the control of an organization by its members, who take part in the making of the decision. In other words democracy implies majority rule and respect for fundamental 
rights of the people. Nwoye (2001) maintains that democracy signifies political system dominated by representatives either directly or indirectly chosen by the people.

Ntalaja (2000:14), succinctly explains democracy as a continuous process of promoting equal access to fundamental rights. According to him, democracy cannot be negotiated as a new bargain to developing nations; rather, it has to be richer than the liberal model, and should be capable of leading to a development strategy that is homegrown, people-centred and oriented towards eradicating poverty. In the same vein, Ake (2001), argued that the real democratic culture that can bring about real development in Africa is the one sustained by economic and political development based on decentralization of power, and reliance on indigenous communities to provide some refuge from the centralized state. Baker (1995) is of the view that democracy is a political system that operates on the basis of popularly elected or appointed representatives to run the affairs of the state. Okafor (1991) notes that democracy is premised on effective representation and participation, adding that while the specificity of democracy differs cross-culturally, there are still basic underlying features that are common and genuine to all democratic processes. Yet, Appadorai (1975:137) describes democracy as a system of government under which the people exercise the governing power either directly or through representatives periodically elected by them.

Democracy is a form of government as well as a way of life, goal, ideal and philosophy which guarantees freedom of the majority and rights of the minority. The World Book (2001), maintains that democracy has certain tenets which include: free elections, majority rule, participation of political parties, unimpeachable judiciary and parliament.

Democracy is an embodiment of the will of the people. Bjornlund et al (1992) put it succinctly thus: 'However, one defines democracy; it is irreducibly a system of government in which the authority to exercise power derives from the will of the people.' 


\section{Democratic Consolidation}

As the new democracies that substituted authoritarian rule in country after country during the seventies and eighties grow out of infancy, social science observers have shifted their focus from the analysis of transitions out of authoritarianism to problems of democratic consolidation. Current queries center on how really democratic the posttransition political institutions are on their long-term prospects; ie., whether they are prone to succumb to a new round of authoritarian rule or whether they will prove to be stable or "consolidated". The modalities assumed by the transition, the way in which political actors are organized, and the various political institutions that emerge or reemerge during the course of the transition are understood to make a significant difference for a long-term viability of newly democratized regimes (Linz, 1985).

The overall change from an authoritarian to a democratic regime contains, as Guillermo O' Donnell \& Valenzuela, (ny) notes, not one but two transitions: the first leads to "installation of a democratic government," and the second to the "consolidation of democracy", or to "the effective functioning of a democratic regime". There is a complex relationship of continuity and discontinuity between the first and second transitions. The building of a consolidated democracy involves in part an affirmation and strengthening of certain institutions, such as the electoral system, revitalized or newly created parties, judicial independence and respect for human rights, which have been created or recreated during the course of the first transition. In this sense, the process of change from one transition to the other is a lineal one. But in many ways there is no such linearity; building a consolidated democracy very often requires abandoning or altering arrangements, agreements, and institutions that may have facilitated the first transition by providing guarantees to authoritarian rulers and the forces backing them but that are inimical to the second.

Scholars have used different definitions of democratic consolidation. These definitions are based on two conceptions of democracy. One is a "minimalist conception", emphasizing procedural or formal democracy. The other is a "maximalist conception," focusing on the outcomes of 
politics, such as institutionalization of political institutions, social justice, and economic equality. Based on the Schumpeterian conception of democracy (that equates democracy, with regularly held electoral competition), Schimitte (1992) defines the minimalist conception of a consolidated democratic regime as "the process of transforming the accidental arrangements, prudential norms, and contingent solutions that have emerged during the transition into relations of cooperation and competition that are reliably known, regularly practiced, and voluntarily accepted by those persons or collectives, that participate in democratic governance.

To Linz, a consolidated democracy is one in which "none of the major political actors, parties, or organized interests, forces or institutions consider(s) that there is any alternative to the democratic process to gain power and that no political institutions or groups has a claim to veto the action of democratically elected decision makers... To put it simply, democracy must be seen as "the only game in town."

In comparison with a minimalist conception of democracy, many scholars adopt "out-come-oriented conceptions" of democracy, or a maximalist conception of democratic consolidation. These scholars argue that both political and socioeconomic democracy is needed for a country's democracy to be consolidated. This conception includes not only procedural or formal democracy but also substantive democratic elements, such as guarantees of basic civil rights, democratic accountability and responsiveness, civilian control over the military, democratic and constitutional checks on executive authority, and punishment of occupational and human rights abuses (Im, 1996:3).

According to Diamond (ny:162), democratic consolidation means the quality, depth, and authenticity of democracy in its various dimensions has been improved: "political competition becomes fairer, freer, more vigorous and executive; participation and representation broader, more autonomous, and inclusive; civil liberties more comprehensively and rigorously protected; accountability more systematic and transparent. 
Linz, et al (1995:79) analyse the extent of democratic consolidation of newly emerging democratic regimes by using the following criteria:

- Structural: this overlaps somewhat with our definition of democracy. It posits that no significant reserve domains of power should exist that prelude important public policies from being determined by the laws, procedures, and institutions that have been sanctioned by the new democratic process.

- Attitudinal: when a strong majority of public opinion acknowledges that the regime's democratic procedures and institutions are appropriate and legitimate, and where support for anti-system alternatives is quite low or isolated from the prodemocratic forces.

- Behavioural: when no significant national, social, economic, political, or institutional actor spends significant resources attempting to achieve its objectives by challenging the regime's institutions or rules with appeals for a military coup or revolutionary activities, and when the prodemocratic forces abide by its rules and do not engage in semi loyal politics.

As Huntington (ny) insists, compared with a maximalist conception of democracy, the minimalist conception provides the analytical precision and empirical referents that make the concept a useful one. Much recent empirical research on democratization also favours a procedural or minimalist conception of democracy (Dahl, 1971).

However, many scholars with a maximalist conception of democracy also have tried to broaden the conception of democracy and to strive for qualitative development of democracy in the world. After all, the two conceptions are quite heuristic in that their usage depends on the scholar's own point of view, as well as on his or her research goals.

Clapham \& Wiseman (eds) (1995:227-228) bluntly suggest that "the consolidation of democracy in Africa also requires a demonstrable relationship between political accountability and the quality of government. Here, as with economic development, there is a potential clash between the principles of accountability which should, in the long term, create more effective systems of government geared to the public 
welfare and in the short-term expedients, such as political patronage, to which elected regimes may be drawn".

\section{Theoretical Framework}

There are many theories of democratic consolidation. These include institutionalization and informal rules.

Institutionalization:

Some scholars think that the process by which a democracy becomes consolidated involves the creation and improvement of secondary institutions of the democracy. Linz and Stephan's thesis (ny), for example, is that democracy is consolidated by the presence of the institutions supporting and surrounding elections. (for example the rule of law)

Informal rules:

O'Donnell (1988), believes that the institutionalization of electoral rules is not the most interesting feature of democratic consolidation. His approach is to compare the formal institutional rules (for example the constitution) with the in formal practices of actors. Consolidation on this view is when the actors in a system follow (have informally institutionalized) the formal rules of the democratic institution.

This study adopts the informal rules approach. This is because, the inability of Nigeria to meet the challenges of rising expectations within the polity as well as lack of accountability and active citizenship have undermined democracy in the country. The operational norm of democracy in Nigeria is less about political competition, but is more about public accountability and active citizenship, and the ability to adhere to the norms has chipped away at governance.

Other factors include the inability of the political leaders to create an environment of shared ownership in the practice of governance and in the generation of ideas needed to govern as well as inability of the state to meet the challenge of rising expectations within the polity.

The increase in the gap between the rich and poor must be addressed and the Millennium Development Goals attained for government to be 
functional. (Kalu, N.K,2O11). Consequently, the research posits that what negate democratic consolidation in Nigeria is the failure of the actors to abide by the norms of democratic governance. As a corollary to this reality, therefore, the study asserts that the antidote to the prevailing stalemate is strict adherence by all politically relevant strata of the Nigerian state to the universally acclaimed of democratic governance.

\section{A critique of 2011 elections in Nigeria} The 2011 Elections

The 2011 General Elections of the Federal Republic of Nigeria were the fourth elections since the country's return to democracy in 1999. The original calendar for the elections foresaw three consecutive Saturdays from 2 to 16 April. However, these dates were subsequently modified for different reasons. Elections took place in the following order: on 9 April for the National Assembly (Senate and House of Representatives) on 16 April the presidential office and on 26 and 28 April, and 6 May for governorships and State Houses of Assembly.

The leading presidential candidates were president Goodluck Jonathan of the Peoples Democratic Party (PDP), the former Head of the Economic and Financial Crimes Commission (EFCC) Nuhu Ribadu of the Action Congress of Nigeria (ACN), the former Head of State, retired General Muhammadu Buhari of the Congress for Progressive Change (CPC) and the then Governor of Kano State Ibrahim Shekarau of the All Nigeria Peoples party (ANPP).

On 2 April, on the Election Day for the National Assembly during a live broadcast at around noon, the INEC chairman, Professor Attahiru Jega informed the public that due to the late arrival of the result sheets in many parts of the country, the National Assembly Elections was postponed to 4 April. On 3 April in another televised speech, Prof. Jega announced that after consultations with the political parties, all the elections were shifted by a week from the original schedule. The new dates were: 9 April National Assembly poll, 16 April Presidential elections and on 26 April. Governorship and state House of Assembly elections. The need to re-print a number of ballot papers was announced 
on 7 April and caused a third postponement for several Senatorial Districts and Federal Constituencies.

Despite the explosion of a bomb on 8 April at the INEC office in Suleja, Niger state that killed eleven people, the repeated National Assembly elections on 9April proved that the decision to postpone the voting was favorable to a positive and peaceful conduct of the Election Day.

On 16 April, the presidential elections were conducted in a generally peaceful and orderly, manner with enthusiastic voters, committed to patiently attend accreditation and voting from early in the morning.

President Goodluck Jonathan of the Peoples Democratic Party (PDP) won the election, defeating his closest rivals, Major-General Muhammadu Buhari of the Congress for Progressive Change (CPC) and Mallam Nuhu Ribadu of the Action Congress of Nigeria (ACN). From the results released, Jonathan polled a total of 22,350,242 votes to beat Buhari, who had 11,914,953 to a distant second, while Ribadu of ACN polled 2,049,357. Shekarau of ANPP polled 1,624,543 votes (Nigeria Tribune, 18 April 2011 p4).

In their various responses to the election, both domestic and foreign observers and commentators described the election as credible. According to the NLC "the presidential and National Assembly elections was the first controversy-free, all inclusive and demonstrably fair and just elections in the country since colonial times (Nigerian Tribune 18 April 2011p3). In a statement entitled: "salute to Nigerians in the aftermath of the presidential elections, "the NLC applauded the sacrifices of the Nigerian populace, who spent hours queuing for accreditation, for the vote, and finally staying behind for the vote count to ensure that their precious votes count".

Observers from the European Union, the Commonwealth and the United States, National Democratic Instituted (NDI), made the outcome of their observation expressing their views on the election process. As M.S, Robin Carnahan, secretary of state of Missouri, United States said, "the presidential election was the second in a series that appears to mark a turning point for African's most populous country". While presenting 
his team's preliminary report, Mr. Alojz Peterce, a former prime minister of Slovenia who was chief observer of the 141-member EU EOM stated that "the presidential elections (last Saturday), means an important step in strengthening democratic elections in the federal republic of Nigeria".

Ms Mariya Nedelcheva, the head of the four-member strong delegation of the European parliament noted that "the elections are a convincing proof that the Nigerian authorities, institutions and electorate, are determined to remain owners of their destiny and to run even better elections the future".

Another preliminary report titled: "Nigeria shakes off stigma of flawed elections," presented by the chairman of the Commonwealth observer group, Mr. Festus Mogae, a former president of Botswana, said Nigeria has now "discarded the notion that the country can only hold flawed elections"... notwithstanding the organizational deficiencies that resulted in the April 2 National Assembly elections being aborted after they had started, and in spite of persistent procedural inconsistencies and technical shortcomings, the elections, the elections for the National Assembly and the presidency were both credible and creditable and reflected the will of the Nigeria people". Mogae said.

Another preliminary report presented by International Republican Institute (IRI), an American-based body that has monitored more than 135 elections in 40 countries asserted that "the overall conclusion is that in at least four areas, the election was different from the previous three elections". As Ms Constance Newman, a member of IRI's Board of Directors observed the areas to include: "the overall integrity of the electoral process, INEC's professionalism, the role of security agencies an reduction in cases of election-related violence".

From the exposition done so far, there was a consensus of opinion among domestic and foreign observers about the sanctity of the 2011 general elections as observable pit falls were not overwhelming as to affect the judgment pendulum to swing in the negative direction (the Nation, April, 19, 2011 p7). 
However, some opposition parties refused to accept the verdict of the election results as announced by INEC. The first party to decline endorsement of the results even before it was formally declared was the Congress for Progressive Change (CPC). The party raised posers about the results from the states in the south-south and south-east. The CPC also criticized results from 22 states and the Federal Capital Territory (FCT). In the petition adopted by the agent of the Action Congress of Nigeria (ACN), Dr Garba Abari at the collation centre at INEC Headquarters, Abuja, CPC demanded a fresh manual re-calculation of the results nationwide and eventually challenged the results in court contrary to its earlier resolve (the Nation, April 19, 2011, p5)

The announcement of the results and the concomitant grievances especially on the part of the supporters of CPC, dovetailed into a state of ambivalence as violence broke out in Kaduna, Gombe, Adamawa, Yobe and Bauchi states. It later spread to other areas in the North as supporters of CPC went on rampage destroying lives and property. Many people were reported killed and properties worth billions of naira destroyed in the violence that assumed a religious dimension. Churches and mosques were not spared in the melee as they were set ablaze by hoodlums (Thisday, April 20, 2011 p 20).

Despite the paradox of primordial reactions that followed the outcome of the 2011 elections, the elections could be said to have marked a democratic leap-forward in the annals of elections in Nigeria

\section{Conclusion}

There is no gainsaying that electoral processes offer a safe, predictable, rule-bound method for arbitrating political and social conflicts through the selection of representatives. When elections are credibly conducted, they imbue the government with legitimacy garnered by the consent of the people, improving the capacity of the state to ensure community security through legitimate authority under the rule of law, and to improve the levels of human development through effective governance. Credible elections create legitimate governments that enjoy popular support for programmes and policies. 
On the other hand, precisely because election processes are contests through which political power is retained or pursued, and social differences are highlighted by candidates and parties campaign for popular support, they can often generate vulnerabilities for the escalation of conflict into violence. This can mean "development in reverse" as incidences of violence undermine government legitimacy, scare away domestic foreign investors, and result in low levels of social trust.(Hoeffler, A and Reynal-Querol, M(2003).

Since it is widely understood that the ultimate guarantor of social peace is robust democratic institutions such as elections, in order to accelerate democratic consolidation drive in Nigeria, incumbent government must provide an unbiased political climate for all political parties and contestants. The so-called "consensus" candidates imposed on parties during façade primary elections should be discountenanced. Zero-sum game which makes politics to assume a war-fare dimension should be de-emphasized. Adequate security mechanisms should be put in place to mitigate violence before, during and after elections. Adequate planning is necessary to enhance the prospects of free and fair election, Abdullahi, Y.S (2008). Candidates and political parties who feel aggrieved with the outcome of the election should seek constitutional means of redressing their disenchantment.

Above all, the national government, the political parties and other election stakeholders must display unequivocal commitment towards free, fair as well as credible elections and democratic consolidation.

\section{References}

Abdullahi,Y.S(2008) Planning Free and Fair Elections in Nigeria in Omodia,SM(2008) Managing Elections in Nigeria,Nigeria: Onaivi Printing and Publishing Co. Ltd

Adejumobi S. (2000). Elections in Africa: A. Fading Shadow of Democracy? International Political Science Review Vol. 21, No 1. 
Adejumobi S. (2002); Democracy \& Good Governance in Africa: Theoretical and Methodological Issues; in A. Bujra and S. Adejumobi (eds) (2002) Breaking Barriers, Creating New Hopes: Democracy, Civil Society \& Good Governance in Africa, Trenton, NJ; Africa World Press.

Adekanbi,D and Akintunde, W(2011) Presidential Poll: Political thugs clash, Nigerian Tribune, April 18, 2011 p3.

Adelaja, O. (2007) Democracy, Elections, Election Monitoring PeaceBuilding in West Africa: in African Journal of International Affairs Vol. 10, Nos 1\&2, 2007.

Adeyomo,A(2011) Anger over Post-Election Violence, Thisday, April 20, 2011 p20

Agbaje, A \& Adejumobi, S (2006) Do Votes Count? The Travails of Electoral Politics in Nigeria; Africa Development Vol. XXX1, No. 3 (CODESRIA).

Ake, C. (2000), The Feasibility of Democracy in Africa, Dakar: CODESRIA.

Appadorai, A. (1978): Substance of Politics, London: Oxford University Press.

Babalola,J(2011) EU, Commonwealth, NDI observers endorse results, The Nation, April 19, 2011 p7.

Bjornlund, E., Bratton, M. and Gibson, C. (1992), 'Observing Multiparty Elections in Africa: Lesson From Zambia, African Affairs, Vol. 91, No. 364.

Dahl, R. (1971), Polyarchy: Participation and Opposition (New Haven, CT: Yale University Press. 
Dahl, R. (2000), Democracy; Yale University Press

Diamond, L. (ny:162) "Democracy in Latin America: Degrees, Illusions \& Directions' for Consolidation', Taiwan Journal of Democracy, Vol. 3, No.1. Encyclopedia Britanica Online, 2009.

European Union Election Observation Mission Final Report,2011.

Eya, N. (2003): Electoral Processes, Electoral Malpractice, and Electoral Violence, Enugu: Sages Publications Nigerian Ltd.

Guillermo, O. D. and Vallenzuela, J. S. (eds), Issues \& Prospects of Democratic Consolidation: The New South American Democracies in Comparative Perspective (Notre Dame, IN: Kellogy Institute Series with University of Notre Dame Press).

Gwinn R. \& Nortan, P. (1992): The New Encyclopedia Britannica, Chicago: University of Chicago Press.

Hoeffler,A and Reynal-Querol(2003) Measuring the Costs of Conflict; Centre for the Study of African Economies, University of Oxford.

Huntington, S. (1984), 'Will More Countries Become Democratic?' Political Science Quarterly, Vol. 99, No.2.

Im, H.B. (1996) "The Prospects for Democratic Consolidation in South Korea: Facilitating and Obstructing Conditions," Paper Presented at the International Conference on Politics $\&$ Security on the Korea Peninsular, Michigan State University.

INEC Guidelines for Election Observation, 2011. Kaplan,A(1964), The Conduct of Inquiry: Methodology for Behavioural Science,Scranton, PA: Chandler Publishing Co. 
Linz, J. (1985), Democracy, Presidential or Parliamentary: Does it make a Difference? World Peace Foundation.

Linz, J. Stephan, A., \& Gunther, R. (1995) "Democratic Transition \& Consolidation in Southern Europe, with Reflections on Latin America \& Eastern Europe," in the Politics of Democratic Consolidation: Southern Europe in Comparatic Perspective; (ed). Gunther, R. Puhle, H. \& Diamondorous, N. (Baltimore, MD: Johns Hopkins University Press.

Makinda, S.M. (1996), Democracy \& Multiparty Politics in Africa; Journal of Modern African Studies 34, No4. 1996.

Ntalaja, N. G. (2000): Democracy and Development in Africa: A Tribute to Claude Ake, Abuja: AFRIGOV.

Nwoye, K. (2001): Corruption, Leadership and the Dialectics' of Development, Enugu: Flight Publishers.

O’Donnell, G. (1988), “Challenges to Democratization in Brazil, "World Policy Journal 5 (Spring (1988).

Okafor, P. (2003): "Transcending Aridity in Nigeria Politics, the Role of Ideas" in SSAN: Nigerian Social Scientists, Volume 6 No 1 March, 2003.

Olson, M. (1993), Disctatorship, Democracy \& Development; American Political Science Review, Vol. 87, No.3.

Olson,M(1993) Dictatorship, Democracy and Development; American Political Science Review, Vol. 87,No.3.

Onyeka, C. (2002): Reducing Malpractices in Our Electoral Process: Presentations at Civic Education Workshops in Anambra State Organized by the Civil Rights Concern and 
TMG, United Nations Electoral Assistance Division, Enugu: CRC Publishers.

Rejai, M. (1967), 'The Metamorphosis of Democratic Theory; Ethics, Vol. 77, No.3. Report of the Political Bureau, Federal Republic of Nigeria, MAMSER, (1987)

Schimitter, P. (1992), "The Consolidation of Democracy \& Representation of Social Groups," American Behavioural Scientists 35 (March/June 1992): 424.

Villalon, L. (1998), 'The African State at the End of the Twentieth Century: Parameters of Critical Juncture,' in, Villalon, L. \& Haxtable, P. (eds), The African State at a Critical Juncture: Between disintegration and re-configuration, London; Lynn Rienner.

Wanyande, P. (1987), 'Democracy and the One Party State: The African Experience: in Oyugi, W. \& Gitonga, A. (eds), Democratic Theory \& Practice in Africa. Nairobi: Heinemann.

Wiseman, J and Clapham,C(1995) Assessing the Prospects for the Consolidation of Democracy in Africa in Democracy and Political Change in Sub-Saharan Africa, London: Routelege.

World Book Encyclopedia (2001) Vol. 5. 